\title{
Biodegradation of Bitumen in Soil and Its Enhancement by Inorganic Fertilizer and Oxygen Release Compound: Experimental Analysis and Kinetic Modelling
}

\author{
Samuel E Agarry ${ }^{1 *}$ and Kigho M Oghenejoboh ${ }^{2}$
}

${ }^{1}$ Biochemical Engineering and Chemical Engineering Biotechnology Laboratory, Department of Chemical Engineering, Ladoke Akintola University of Technology, Nigeria ${ }^{2}$ Department of Chemical Engineering, Delta State University, Nigeria

\begin{abstract}
The objective of this work was to investigate and evaluate the effect of inorganic nutrient (NPK fertilizer), hydrogen peroxide and their combinations on the kinetics of bitumen degradation by autochthonous microorganisms in the soil. The study was carried out by artificially contaminating an un-impacted tropical soil with $40 \mathrm{~g} / \mathrm{kg}$ of bitumen in plastic bins and amended with various amount of NPK fertilizer $(1.63 \mathrm{~g}, 2.10 \mathrm{~g}$ and $2.56 \mathrm{~g})$, hydrogen peroxide $(0.5 \mathrm{~g}$ and $1.0 \mathrm{~g})$ and combinations of NPK fertilizer and hydrogen peroxide $(2.13 \mathrm{~g}, 2.60 \mathrm{~g}$ and $3.06 \mathrm{~g})$, respectively. The bioremediation was carried out for 21 days. Results showed that inorganic NPK fertilizer, hydrogen peroxide and their combinations stimulated microbial growth and enhanced bitumen biodegradation. The bacterial count and percentage total petroleum hydrocarbon degradation relatively increased with increase in the amount of inorganic nutrient and oxygen release compound used in this study. More than $50 \%$ of the hydrocarbons were degraded within each remediation period. The combined addition of inorganic NPK fertilizer and hydrogen peroxide provided the highest percentage biodegradation $(>60 \%)$. Under abiotic conditions, no total petroleum hydrocarbon removal was observed while a maximum of $10.8 \%$ total petroleum hydrocarbons removal was obtained in unamended soil (natural attenuation) experiment. A first-order kinetic model successfully described the bitumen biodegradation. The model revealed that bitumen contaminated-soil microcosms amended with inorganic nutrient and oxygen release compound had higher biodegradation rate constants, as well as lower half-life times, than unamended soil (natural attenuation) remediation system. The biodegradation rate constant was higher with lower half life time as the amount of inorganic nutrient and oxygen release compound in soil increased.
\end{abstract}

Keywords: Bioremediation; Biodegradation; Biostimulation; Bitumen; First-order kinetics; Half-life

\section{Introduction}

Petroleum is a complex mixture of hydrocarbons formed from the geologic transformation and decomposition of plants and animals that lived hundreds of millions of years ago [1]. Generally, petroleum encompasses the liquid (crude oil), gaseous (natural gas), and viscous or solid (bitumen asphalt) forms of hydrocarbons that occur in the Earth, however, the meaning is often restricted to the liquid oil form. Nigeria is blessed with vast deposits of natural bitumen [2] with a proven reserve of 42.47 billion metric tonnes, the second largest in the world, covering about $120 \times 4.3 \mathrm{~km}$ [3]. Bitumens are classified into following groups: Mineral waxes, Asphalts, Asphaltites and Oil-shale bitumen. Bitumen mixed with mineral matter is defined as asphalt. Bitumens are solid or semisolid hydrocarbons which are sticky, black and highly viscous [4]. It exhibits thermoplastic behaviors softening when heated, becoming mobile liquids on further heating and returning to their original state on cooling. They are naturally occurring substances that are considered to be complex mixtures of high-molecular-weight hydrocarbons with relatively low hydrogen to carbon ratio [5] and nonhydrocarbons which can be separated into fractions consisting of oily material, resins, asphaltenes, and carbenes. These fractions merge into one another and their atomic $\mathrm{C} / \mathrm{H}$ ratio increases with each succeeding member, except for the carbenes which differ mainly in having more oxygen than the asphaltenes. Three types of hydrocarbons are present in bitumens: paraffinic, naphthenic, and aromatic hydrocarbons. Non-hydrocarbons in bitumen have heterocyclic atoms consisting of sulphur, nitrogen, [6], iron and vanadium [7].

Petroleum hydrocarbons cause a variety of risks when released in a relatively high concentration into the environment. It is physically, chemically and biologically harmful to soil because of its toxicity. It can cause chronic sub-acute toxicological effect (reduced growth and reproduction, poor health, low recruitment rates), which can alter population dynamics and disrupt tropic interactions and the structure of natural communities within ecosystems [8].

The remediation processes leading to the eventual removal of these petroleum hydrocarbons from the environment involve the trio of physical, chemical and biological alternatives [9]. Bioremediation technologies are currently receiving favourable attention as promising cost effective and environmentally friendly treatment technologies for the remediation hydrocarbons $[10,11]$. Bioremediation is the application of biological treatment to clean up environment contaminated with hazardous chemicals. It involves detoxification where the pollutant may be converted to less toxic substances and mineralization, where the waste material can be converted into inorganic compounds such as carbon dioxide, water, methane and sometimes fatty acids [12]. Bioremediation is not new to human race but new approaches that stem from advances in molecular biology and process engineering are

*Corresponding author: Samuel E Agarry, Biochemical Engineering and Chemical Engineering Biotechnology Laboratory, Department of Chemical Engineering, Ladoke Akintola University of Technology, P. M. B. 4000, Ogbomoso, Nigeria, Tel/ Fax: +23 48055529 705; E-mail: sam_agarry@yahoo.com

Received July 20, 2014; Accepted August 14, 2014; Published August 21, 2014

Citation: Agarry SE, Oghenejoboh KM (2014) Biodegradation of Bitumen in Soil and Its Enhancement by Inorganic Fertilizer and Oxygen Release Compound: Experimental Analysis and Kinetic Modelling. J Microbial Biochem Technol S4 002. doi:10.4172/1948-5948.S4-002

Copyright: (C) 2014 Agarry SE, et al. This is an open-access article distributed under the terms of the Creative Commons Attribution License, which permits unrestricted use, distribution, and reproduction in any medium, provided the original author and source are credited 
Citation: Agarry SE, Oghenejoboh KM (2014) Biodegradation of Bitumen in Soil and Its Enhancement by Inorganic Fertilizer and Oxygen Release Compound: Experimental Analysis and Kinetic Modelling. J Microbial Biochem Technol S4: 002. doi:10.4172/1948-5948.S4-002

Page 2 of 8

emerging. Microbes bioremediate the environment as they biodegrade the pollutant to obtain carbon and energy, Biodegradation specifically refers to chemical breakdown or mineralization of materials facilitated by biological organisms or products [13].

Nonetheless, biodegradation efficiencies of petroleum hydrocarbons in soil can be limited by physicochemical as well as biological factors, such as nutrients, $\mathrm{pH}$, temperature, oxygen, number and type or species of microorganisms [14,15]. Thus, petroleum hydrocarbon pollution tends to persist in soils until bioremediation measures, involving the application of nutrients are resorted to, because oxygen and nitrogen are limiting factors in all types of petroleum degradation. Oxygen levels must be high enough for the breakdown of hydrocarbons. Thus, pollutant degradation rates can be enhanced by the addition of nutrients, oxygen, and primary substrates into the contaminated systems. This could increase the populations of indigenous microorganisms and thus improve the efficiency of pollutant biodegradation. Biostimulation can be considered as an appropriate remediation technique for petroleum hydrocarbon removal in soil and requires the evaluation of both the intrinsic degradation capacities of the autochthonous microflora and the environmental parameters involved in the kinetics of the in situ process. In biostimulation technology, nutrient supplementation for petroleum hydrocarbon degradation has traditionally focused on addition of nitrogen $(\mathrm{N})$ and phosphorus $(\mathrm{P})$, either organically or inorganically. The effects of nutrients (i.e. NPK), aeration and biostimulation of indigenous soil microorganisms and inoculation of extraneous microbial consortia on the bioremediation of oil contaminated soil have been investigated $[16,17]$.

In recent times, researchers have focused on the use of OxygenRelease Compounds (ORCs) to promote the direct oxidation of pollutants and, at the same time, to increase aerobic microbial degradation [18-22]. The introduction of pure oxygen rather than air can significantly increase the Dissolved Oxygen (DO) concentrations [18]. Injection of hydrogen peroxide $\left(\mathrm{H}_{2} \mathrm{O}_{2}\right)$ is one of the methods to increase the DO concentrations. A significant portion of contaminants in soils has been found to be oxidized by $\mathrm{H}_{2} \mathrm{O}_{2}$ without any addition of soluble iron $[18,23]$ and the mineral catalyzed Fenton-like reaction was proposed to describe the oxidation occurring in the natural soils. One of the advantages of applying Fenton-like oxidation for contaminant oxidation is that the produced oxygen during the decomposition of $\mathrm{H}_{2} \mathrm{O}_{2}$ would increase the DO concentration. This would enhance the aerobic biodegradation rate of contaminant [24]. The exploitation and exploration of the Nigerian natural bitumen deposits can best be described to be at the planning stage [25]. According to Olabemiwo et al. [25], major studies on the Nigerian bitumen were concentrated on geological surveying of the deposits and the composition and engineering properties of the bitumen. Nevertheless, very few studies on the potential biodegradation of bitumen by bacterial monoculture and consortium has been reported $[1,25,26]$, however, there is a dearth of information on the use of inorganic fertilizer (NPK) and ORC for biostimulation of autochthonous microflora in the bioremediation of bitumen contaminated soils. Therefore, the objective of this work was to study the bioremediation of soil artificially contaminated with Nigerian bitumen via biostimulation strategy, using inorganic fertilizer (NPK 20:10:10) and oxygen release compound (hydrogen peroxide) as biostimulating agents; and to evaluate their effects on the kinetics of bitumen biodegradation.

\section{Materials and Methods}

\section{Source and collection of samples}

An un-impacted soil samples used for the study was collected from the surface layer of the vadose zone $(15-30 \mathrm{~cm})$ below land surface of Ladoke Akintola university of Technology (LAUTECH) agricultural farm land, Ogbomoso, Nigeria. The soil samples were air dried, homogenized, passed through a 2-mm (pore size) sieve and stored in a polyethylene bag and kept in the laboratory prior to use. Bitumen samples were obtained from Agbabu village in Ondo State of Nigeria. It was collected from the well located at the back of the King's palace. Agbabu is the place where bitumen was first discovered in Nigeria in 1910 [2] and the first bitumen well NBC-7 was drilled there.

\section{Soil sample and bitumen characterization}

Soil samples were characterized for their physicochemical parameters according to standard methods. Total organic carbon and Total Nitrogen of soil were determined using Walkley-Black and MacroKjeldahl methods respectively $[27,28]$. Soil $\mathrm{pH}$ was determined using $\mathrm{pH}$ meter fitted with a combined glass $\mathrm{pH}$ and reference electrode. Soil moisture content was determined by evaporation on Whatman filter paper NO 1 (BDH Chemicals England) at $103^{\circ}$ to $105^{\circ} \mathrm{C}$ in an electrical oven. Available phosphorus was determined using Bray NO 1 Method $[27,28]$. The determined soil parameter values are as follows: moisture content $11 \pm 0.2 \%$, total nitrogen $0.25 \pm 0.04 \%$, available phosphorus $0.10 \pm 0.03 \%$, potassium $0.28 \pm 0.04 \%$, and total organic carbon $1.15 \pm$ $0.02 \%, \mathrm{pH} 7 \pm 0.2$. The soil characterization showed that the soil did not fulfill the nutrient (NPK) requirements for an efficient biodegradation process. Therefore, these elements were added in the form of NPK inorganic fertilizer (20:10:10) to provide the proper nutrients required for the biodegradation process. The elemental compositions of the bitumen were carried out on a Carlo Erba NA 1500 C/N/S Analyzer. The determined elemental composition percentage by weight of the bitumen is: carbon $81.5 \%$, hydrogen $10.56 \%$, sulphur $0.73 \%$, oxygen $1.49 \%$ and nitrogen $0.99 \%$.

\section{Bioremediation of bitumen-spiked soil}

Bioremediation experiments were conducted in plastic bin reactor with a volume of about $3 \mathrm{~L}$. Soil samples $(1 \mathrm{~kg})$ were artificially contaminated with bitumen to a level of $40 \mathrm{gkg}^{-1}$. The bitumencontaminated soil was transferred into each reactor (microcosm) and the soil humidity was adjusted to $20-25 \%$, which corresponds to $70-80 \%$ of the soil water holding capacity [29]. The microcosms were amended with: (i) $15: 15: 15$ NPK fertilizer (1.63, 2.10 and 2.56 g) (ii) Hydrogen peroxide $(0.5$ and $1.0 \mathrm{~g})$ and (iii) NPK fertilizer and hydrogen peroxide mixture in the ratio 3.3:1, 4.2:1 and 5.1:1 equivalent to a total amount of $2.13 \mathrm{~g}, 2.60 \mathrm{~g}$ and $3.06 \mathrm{~g}$, respectively. Soil used as control was sterilized by autoclaving at $121^{\circ} \mathrm{C}$ and 15 psi for $1 \mathrm{~h}$ for three alternate days [30] before contamination with bitumen and was further treated with the biocide $\mathrm{HgCl}$ as an abiotic control to show the effect of evaporation and other physical reactions in the absence of microbial activity. A natural attenuation test was carried out; the bioreactors were prepared without NPK or hydrogen peroxide supplementation. All tests were conducted in triplicate. In total, 30 microcosms were settled and incubated for three weeks ( 21 days). To guarantee oxygen supply, the soil was aerated manually every $72 \mathrm{~h}$ using a glass stirring rod. Soil sampling for residual bitumen in terms of Total Petroleum Hydrocarbon (TPH) and total heterotrophic bacteria analysis was carried out at intervals of 7 days by collecting $10 \mathrm{~g}$ of the soil from three equidistant locations. This was performed to mix and to homogenize the soil samples to get a unique final sample. 
Citation: Agarry SE, Oghenejoboh KM (2014) Biodegradation of Bitumen in Soil and Its Enhancement by Inorganic Fertilizer and Oxygen Release Compound: Experimental Analysis and Kinetic Modelling. J Microbial Biochem Technol S4: 002. doi:10.4172/1948-5948.S4-002

\section{Determination of microbial (total hydrocarbon-degrading bacteria) count}

Quantification of the Total Hydrocarbon-Degrading Microorganisms (THDB) present in the soil samples was determined at the beginning of the experiment (time zero) and after 7, 14 and 21 days of remediation time by the pour plate count technique. Soil samples $(10$ g) was transferred into sterilized Erlenmeyer conical flasks containing $90 \mathrm{~mL}$ of sterile $0.9 \%(\mathrm{~m} / \mathrm{v}) \mathrm{NaCl}$ solution and then shaken in a shaker for $15 \mathrm{~min}$ at $150 \mathrm{rpm}$. Samples $(1 \mathrm{~mL})$ were subjected to a serial 10 -fold dilution procedure and cultivated in a nutrient agar medium. Three plates were inoculated for each dilution. The plates were incubated at $30^{\circ} \mathrm{C}$ for $48 \mathrm{~h}$ and the number of colony forming units (CFU) was counted in each sample. The results were expressed as colony-forming units per gram of dry soil (CFU/g dry soil). All microbiological counts and experiments were carried out in triplicate. The hydrocarbon degrading bacterial types isolated from the soil samples were mainly Acinetobacter, Bacillus, and Pseudomonas species.

\section{Extraction of residual bitumen and determination of total petroleum hydrocarbon}

The extent of utilization of the Total Petroleum Hydrocarbon (TPH) in the bitumen was estimated gravimetrically. The procedure for the extraction of bitumen residues in soil was performed according to Quintero et al. [31], as follows: (i) aliquots of $5 \mathrm{~g}$ of dry homogenized soil were transferred to a centrifuge tubes and mixed with 4:1:5 watermethanol-hexane solutions. (ii) The tubes were hermetically sealed and shaken for $10 \mathrm{~min}$ in a vortex in order to attain the transport of bitumen from soil to the organic phase and centrifuged at $2500 \mathrm{rpm}$ for $10 \mathrm{~min}$ with the formation of two different layers. The upper layer which was organic phase layer contained biodegraded bitumen and lower layer was aqueous phase. (iii) The organic phase layer was collected into a pre-weighed beaker using separating funnel. The process was repeated thrice and the combined organic phase layer was allowed to evaporate to dryness at room temperature and the beaker and its content was weighed. The extracts were re-dissolved in n-hexane and taken for gas chromatography analysis. Residual bitumen in terms of TPH extracted from soil was analyzed in a Hewlett- Packard GC-FID (HP 6890) equipped with Flame Ionization Detector (FID) and a fused silica capillary column $(30 \mathrm{~m} \times 0.25 \mu \mathrm{m} \times 0.25 \mu \mathrm{m}$ film thickness. Nitrogen was the carrier gas and flow at a rate of $30 \mathrm{ml} \mathrm{min}^{-1}$ and pressure of 30 psi. For the quantification of aliphatic hydrocarbons, all runs were carried out under the following conditions: initial column temperature $60^{\circ} \mathrm{C}$; was held isothermally for $2 \mathrm{~min}$ and was increased to $260^{\circ} \mathrm{C}$ at a heating rate of $10^{\circ} \mathrm{C} / \mathrm{min}$ for $20 \mathrm{~min}$. It was isothermally held at this temperature for $2 \mathrm{~min}$ and thereafter increased to $320^{\circ} \mathrm{C}$ at a heating rate of $12^{\circ} \mathrm{C} / \mathrm{min}$ for $5 \mathrm{~min}$. The injector and detector temperatures were $250^{\circ} \mathrm{C}$ and $350^{\circ} \mathrm{C}$, respectively. For the quantification of aromatic hydrocarbons, all runs were carried out under the following conditions: initial column temperature $68^{\circ} \mathrm{C}$ and was held at this temperature for $2 \mathrm{~min}$ after which it was increased to $260^{\circ} \mathrm{C}$ at a heating rate of $12^{\circ} \mathrm{C} /$ $\min$ for $16 \mathrm{~min}$. It was isothermally held at this temperature for $4 \mathrm{~min}$ and then increased to $320^{\circ} \mathrm{C}$ at a heating rate of $15^{\circ} \mathrm{C} / \mathrm{min}$ for $4 \mathrm{~min}$ and maintained at this temperature for $8 \mathrm{~min}$. The injector and detector temperatures were $300^{\circ} \mathrm{C}$ and $320^{\circ} \mathrm{C}$, respectively. Sample volume injected was $2 \mu \mathrm{l}$ [32]. Calibration curves for the aliphatic and aromatic hydrocarbons were prepared using their standard solutions supplied by manufacturer of the equipment.

\section{Kinetic model analysis}

Kinetic analysis is a key factor for understanding biodegradation process, bioremediation speed measurement and development of efficient clean up for a petroleum hydrocarbon contaminated environment. The information on the kinetics of soil bioremediation is of great importance because it characterizes the concentration of the contaminant remaining at any time and permit prediction of the level likely to be present at some future time. Petroleum hydrocarbon biodegradation rates are usually difficult to predict due to the complexity of the environment [33]. Nevertheless, biodegradation rate of organic compounds by microorganisms is often described by the equation as follows [34]:

$$
q=\frac{q_{m} c}{k+c}
$$

Where $q$ is biodegradation rate, $q_{\mathrm{m}}$ is maximum specific biodegradation rate, $c$ is the substrate concentration and $k$ is halfsaturation constant. If $c$ « $k$; Eq. (1) can be reduced to:

$$
q=\frac{q_{m} c}{k}
$$

Eq. (2) is a typical first-order model. The use of first-order kinetics in the description of biodegradation rates in environmental fate models is common because mathematically the expression can be easily incorporated into the model [30]. Assuming

$$
k_{1}=\left(q_{m} / k\right)
$$

and integrating Eq. (2), the following relation of substrate concentration to time can be obtained as given in Eq. (3):

$$
\ln c=a+k_{1} t
$$

\section{Estimation of biodegradation half-life times}

The biological half-life is the time taken for a substance to lose half of its amount. Biodegradation half-lives are needed for many applications such as chemical screening [35], environmental fate modeling [36] and describing the transformation of pollutants $[37,38]$. Biodegradation half-life times $\left(t_{1 / 2}\right)$ are calculated by Eq. (4) $[39,40]$ :

$$
t_{1 / 2}=\frac{\ln 2}{k}
$$

Where is the biodegradation rate constant $\left(\mathrm{day}^{-1}\right)$. The half-life model is based on the assumption that the biodegradation rate of hydrocarbons positively correlated with the hydrocarbon pool size in soil [41].

\section{Data analysis}

The data were subjected to one-way analysis of variance (ANOVA) at $5 \%$ probability. The data analysis was performed using statistical package for social sciences, version 16.0 (SPSS Inc., Chicago, IL, USA).

\section{Results and Discussion}

\section{Removal of total petroleum hydrocarbons}

The level of bitumen biodegradation in soil amended with different amount of inorganic NPK fertilizer, hydrogen peroxide and combination of NPK fertilizer and hydrogen peroxide are shown in Figure $1 \mathrm{a}, \mathrm{b}$ and $\mathrm{c}$. Figure 1a shows the degradation profile of bitumen in soil as a function of remediation time for $1.63 \mathrm{~g}, 2.10 \mathrm{~g}$ and 2.56 $\mathrm{g}$ of inorganic NPK nutrient amendment, respectively. Figure 1 revealed that the petroleum hydrocarbon degradation began during the first week of remediation time in all the treatments and slowly continued up to the third week. The \% TPH degradation in the first 

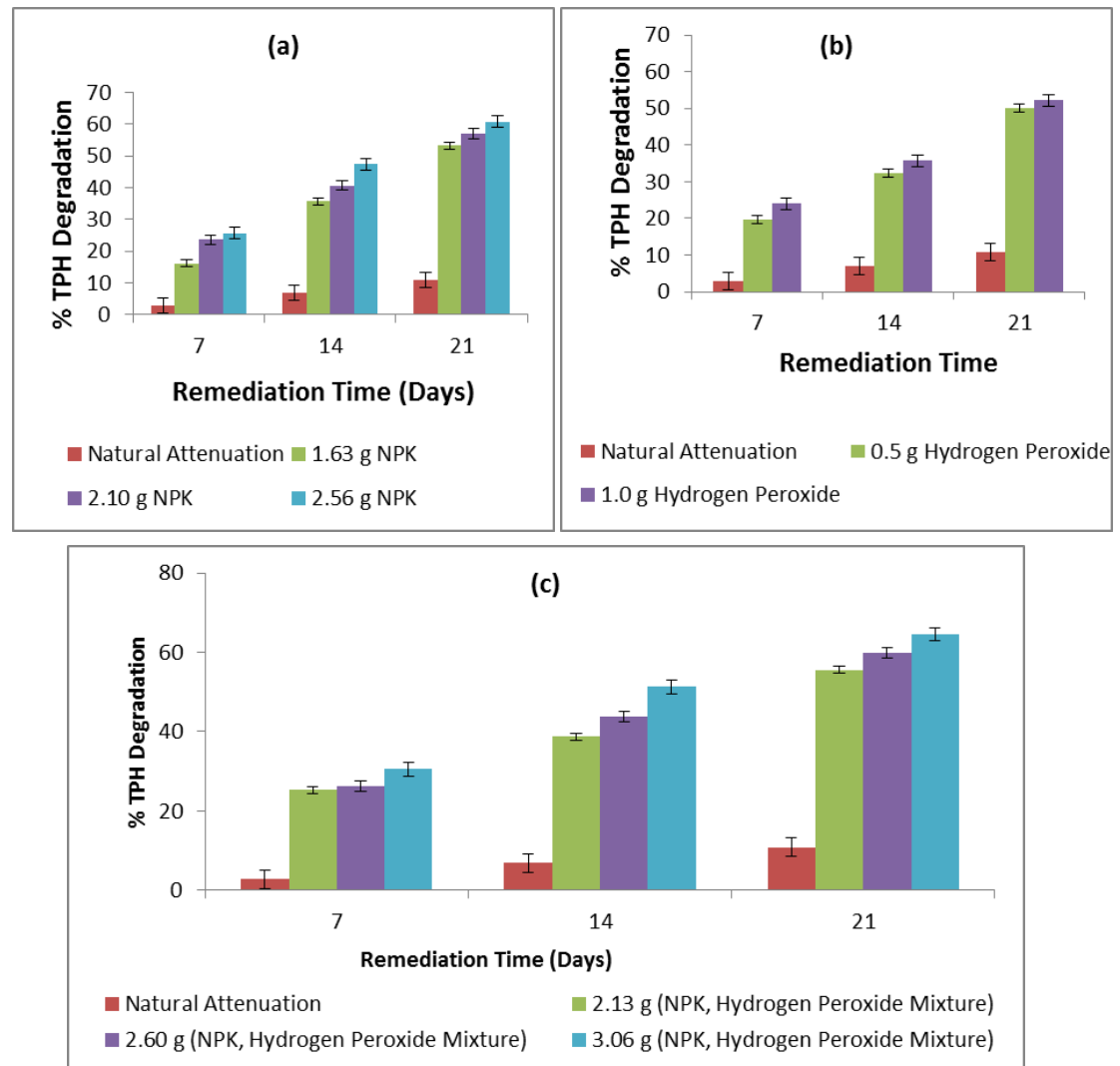

Figure 1: Time course for the of biodegradation of bitumen under the influence of (a) varying amount of NPK fertilizer, (b) varying amount of hydrogen peroxide, and (c) varying amount of combined NPK fertilizer+hydrogen peroxide. Bars indicate the average of triplicate samples while the error bars show the standard deviation.

week of remediation was $16.2,23.6$ and $25.6 \%$ for soil amended with $1.63 \mathrm{~g}, 2.10 \mathrm{~g}$ and $2.56 \mathrm{~g}$ of NPK fertilizer, respectively. At the end of the remediation time (day 21), there was $53.2 \%, 57 \%$ and $60.8 \% \mathrm{TPH}$ degradation in soil amended with $1.63 \mathrm{~g}, 2.10 \mathrm{~g}$ and $2.56 \mathrm{~g}$ of NPK fertilizer, respectively, while $10.8 \% \mathrm{TPH}$ degradation was observed in unamended soil (natural attenuation). These observations indicates that degradation of petroleum hydrocarbons in bitumen was relatively higher at a greater amount of inorganic NPK fertilizer and that amendment with inorganic fertilizer enhanced the biodegradation (biostimulation) in comparison with the unamended contaminated soil (natural attenuation). Similar observations have been reported for the use of NPK fertilizer in the biodegradation of crude oil [16], petroleum hydrocarbon mixtures [17] and fuel oil, diesel and kerosene [12]. It has been reported that the addition of nitrogenous nutrient enhances biodegradation of hydrocarbon-polluted soil, presumably by removing the nitrogen limitation resulting from low natural level $[40,42]$.

Figure $1 \mathrm{~b}$ shows the degradation profile of bitumen in soil as a function of remediation time for $0.5 \mathrm{~g}$ and $1.0 \mathrm{~g}$ of hydrogen peroxide (oxygen release compound) amendment, respectively. It is seen from Figure 2 that the petroleum hydrocarbon degradation began during the first week of remediation time in all the treatments and slowly continued up to the third week. The \% TPH degradation in the first week of remediation was 19.6 and $24 \%$ for soil amended with $0.5 \mathrm{~g}$ and $1.0 \mathrm{~g}$ of hydrogen peroxide, respectively. At the end of the remediation time (day 21 ), there was $50.1 \%$ and $52.2 \%$ TPH degradation in soil amended with $0.5 \mathrm{~g}$ and $1.0 \mathrm{~g}$ of hydrogen peroxide, respectively, while $10.8 \%$ TPH degradation was observed in unamended soil (natural attenuation). These observations indicates that degradation of petroleum hydrocarbons in bitumen was relatively higher at a greater amount of hydrogen peroxide and that amendment with oxygen release compound (hydrogen peroxide) enhanced the biodegradation (biostimulation) in comparison with the unamended contaminated soil (natural attenuation). Similar observations have been reported for the biodegradation of diesel [21], kerosene [20,21], pyrene [19], benzene, toluene and xylene [43], fuel-oil [18], and crude oil $[21,44]$. Furthermore, at the Traverse city, Michigan, bioremediation of a contaminated site was achieved by an increase in the oxygen concentration in water through addition of hydrogen peroxide and was observed to positively affect the rate of biodegradation [45].

The biodegradation profile of bitumen contaminated soil amended with two level combinations of inorganic NPK fertilizer and hydrogen peroxide is shown in Figure 1c. A rapid TPH reduction was observed within the first week (day 7) for each combination treatment. During this period, there was $25.3 \%, 26.2 \%$ and $30.5 \% \mathrm{TPH}$ reduction in soil amended with $2.13 \mathrm{~g}$ (NPK, hydrogen peroxide mixture), $2.60 \mathrm{~g}$ (NPK, hydrogen peroxide mixture) and $3.06 \mathrm{~g}$ (NPK, hydrogen peroxide, mixture) respectively. The $\% \mathrm{TPH}$ degradation (or reduction) increased to $55.6 \%, 60 \%$ and $60.4 \%$ at the end of remediation time (day 21 ) in soil amended with $2.13 \mathrm{~g}$ (NPK, hydrogen peroxide mixture), $2.60 \mathrm{~g}$ (NPK, hydrogen peroxide mixture) and $3.06 \mathrm{~g}$ (NPK, hydrogen peroxide, mixture, respectively; while $10.8 \% \mathrm{TPH}$ degradation was observed in unamended soil (natural attenuation). A similar observation has been reported for the combination of nitrogen, phosphorus and hydrogen peroxide in the biodegradation of diesel, kerosene, used engine oil and 


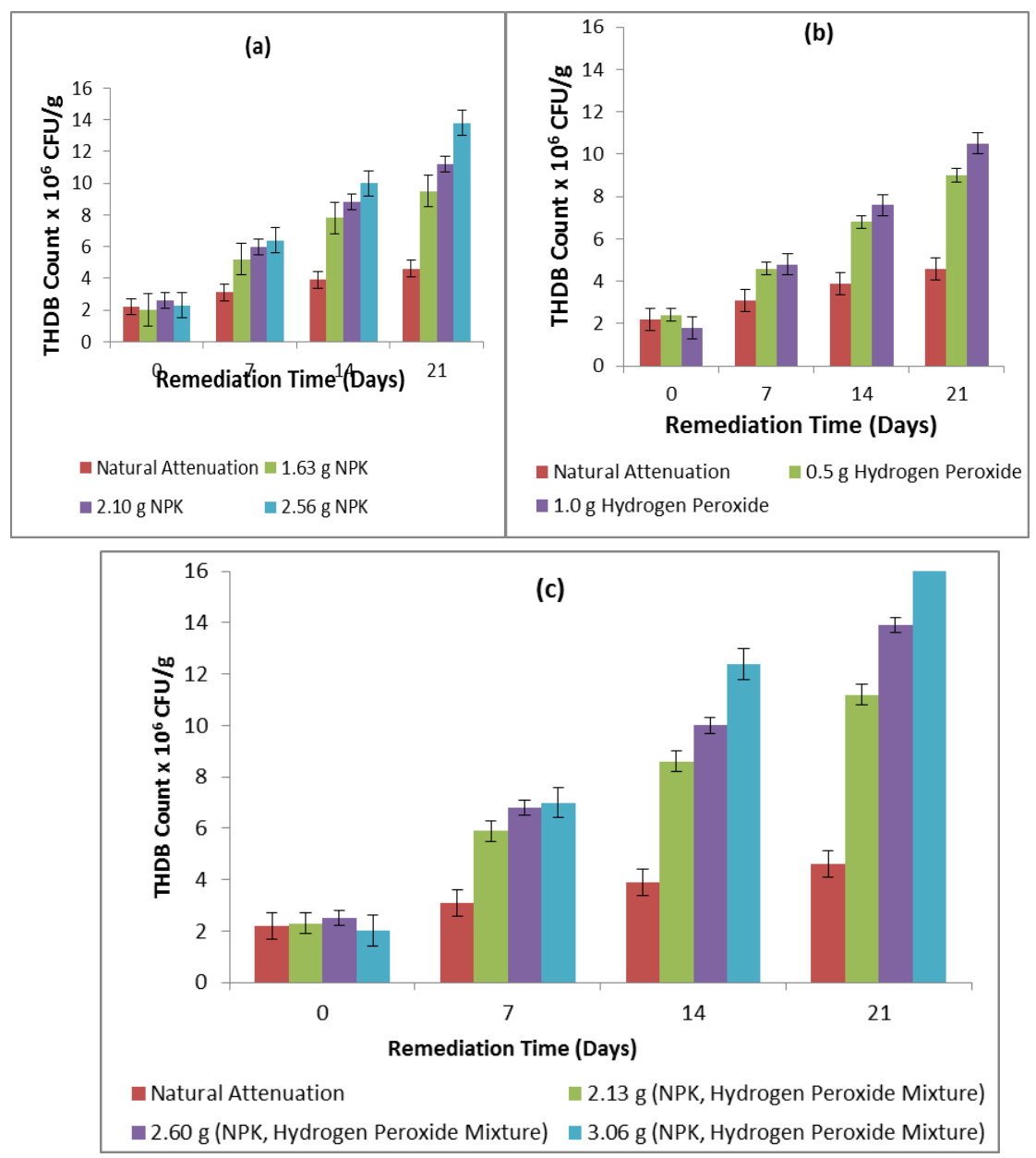

Figure 2: Time course for the growth of Total Hydrocarbon Degrading Bacteria (THDB) under the influence of (a) varying amount of NPK fertilizer, (b) varying amount of hydrogen peroxide, and (c) varying amount of combined NPK fertilizer+hydrogen peroxide. Bars indicate the average of triplicate samples while the error bars show the standard deviation.

crude oil by Bacillus cereus [21]. On the other hand, no reduction in TPH was observed in the control microcosm where the soil had been autoclaved three times at $121^{\circ} \mathrm{C}$ for 30 minutes each and $\mathrm{HgCl}$ treated (Figure 1a-1c). This observation indicates the role and importance of intrinsic or autochthonous microorganisms in the biodegradation process of organic contaminants present in the environment [40]. That is, the efficiency of bioremediation is a function of the microbial viability in the natural environment [46]. Nonetheless, the interaction between the NPK and oxygen release compound (hydrogen peroxide) in the amended contaminated soil suggest to impact on the intrinsic microbial populations a higher growth rate and thus higher count and higher hydrocarbon degradation as compared to inorganic NPK fertilizer or oxygen release compound being used alone/singly.

\section{Microbial growth}

Figure 2a-2c shows the growth profiles of the Total Hydrocarbon Degrading Bacteria (THDB) in bitumen contaminated soil amended with different amount of inorganic NPK fertilizer, hydrogen peroxide and combination of NPK fertilizer and hydrogen peroxide, respectively.

Generally, it is seen that the microbial (THDB) counts increased from Day 0 to Day 21 in each of the four treatment microcosms.
For NPK-soil amended microcosms, the THDB count increased from 2 to $9.5 \times 10^{6} \mathrm{CFU} / \mathrm{g}$; 2.6 to $11.2 \times 10^{6} \mathrm{CFU} / \mathrm{g}$; and 2.3 to $13.8 \times 10^{6}$ CFU/g for $1.63 \mathrm{~g}, 2.10 \mathrm{~g}$ and $2.56 \mathrm{~g}$ of supplemented NPK fertilizer, respectively (Figure 2a). While for the unamended soil microcosm (natural attenuation), the THDB increased from 2.2 to $4.6 \times 10^{6} \mathrm{CFU} / \mathrm{g}$. This showed that the soil microcosms amended with inorganic NPK fertilizer (biostimulation) enhanced the microbial growth rate which accounted for the higher bacterial counts than the unamended soil microcosm (natural attenuation). In addition, it indicated that higher microbial counts were observed for microcosms with relatively higher amount of inorganic NPK fertilizer. The higher microbial count in microcosms with biostimulation may be due to high nutrient level, which stimulated an increase in microbial population and activities, thus leading to high energy (carbon) demand by the hydrocarbondegrading microorganisms. This has resulted in the increased reduction of the Total Petroleum Hydrocarbon (TPH) in the remediation treatments. Similar observations have been reported $[12,47,48]$. The lower bacteria population in natural attenuation treatment may be due to the presence of low nutrients. Zhou and Crawford [49] pointed out that under low nutrient conditions, microorganisms did not have enough nutrients for optimal growth; hence rate of biodegradation 
is low. And, under higher nutrient conditions, an optimal microbial growth is likely favored which elicits higher biodegradation rate. Knowledge of bioavailability of nutrients is necessary in the planning of an efficient bioremediation strategy [50].

For oxygen release compound (hydrogen peroxide)-soil amended microcosms; the THDB count increased from 2.4 to $9.0 \times 10^{6} \mathrm{CFU} / \mathrm{g}$ and 1.8 to $10.5 \times 10^{6} \mathrm{CFU} / \mathrm{g}$ for $0.5 \mathrm{~g}$ and $1.0 \mathrm{~g}$ of supplemented hydrogen peroxide (Figure $2 \mathrm{~b}$ ). While for the unamended soil microcosm (natural attenuation), the THDB increased from 2.2 to $4.6 \times 10^{6} \mathrm{CFU} / \mathrm{g}$. This revealed that the soil microcosms amended with oxygen release compound (biostimulation) enhanced the microbial growth rate which accounted for the higher bacterial counts than the unamended soil microcosm (natural attenuation). Furthermore, it showed that relatively higher microbial counts were observed for microcosms with relatively higher amount of oxygen release compound. The higher microbial count in microcosms with oxygen release compound (hydrogen peroxide) may be due to the presence of relatively high amount of oxygen level, which stimulated an increase in hydrocarbon degradation (utilization for carbon and energy) by the hydrocarbondegrading microorganisms; which therefore resulted in higher microbial growth. Similar observations have been reported [18,19,22].

The THDB count increased from 2.3 to $11.2 \times 10^{6} \mathrm{CFU} / \mathrm{g} ; 2.5$ to $13.9 \times 10^{6} \mathrm{CFU} / \mathrm{g}$; and 2.0 to $17.2 \times 10^{6} \mathrm{CFU} / \mathrm{g}$ for contaminated soil amended with $2.13 \mathrm{~g}$ (NPK, hydrogen peroxide mixture), 2.60 $\mathrm{g}$ (NPK, hydrogen peroxide mixture) and $3.06 \mathrm{~g}(\mathrm{NPK}$, hydrogen peroxide, mixture, respectively (Figure $2 \mathrm{c}$ ). While for the unamended soil microcosm (natural attenuation), the THDB increased from 2.2 to $4.6 \times 10^{6} \mathrm{CFU} / \mathrm{g}$. This observation showed that soil microcosms amended with the combination of inorganic NPK fertilizer and oxygen release compound (biostimulation) enhanced the microbial growth rate which accounted for the higher bacterial counts than the unamended soil microcosm (natural attenuation). Nonetheless, the interaction between the NPK and oxygen release compound (hydrogen peroxide) in the amended contaminated soil suggest to impact on the intrinsic microbial populations a higher growth rate and thus higher count as compared to inorganic NPK fertilizer or oxygen release compound being used alone/singly.

\section{Evaluation of biodegradation kinetics and half-life}

First-order kinetics model equation (Eq. 2) fitted to the biodegradation data (Figure 3a-3c) was used to determine the rate of bitumen biodegradation in the various remediation treatments. The values of the rate constants obtained from fitting of the model are presented in Table 1.

The results in Table 1 as indicated by the high correlation determination $\left(R^{2}\right)$ showed that the biodegradation of bitumen fitted well to the first-order kinetic model. The half-life time of bitumen biodegradation was calculated using Eq. (4). The biodegradation rate constants $(k)$ and half-life times $\left(t_{1 / 2}\right)$ for the different remediation treatments are presented in Table 1 . It is to be noted that the higher

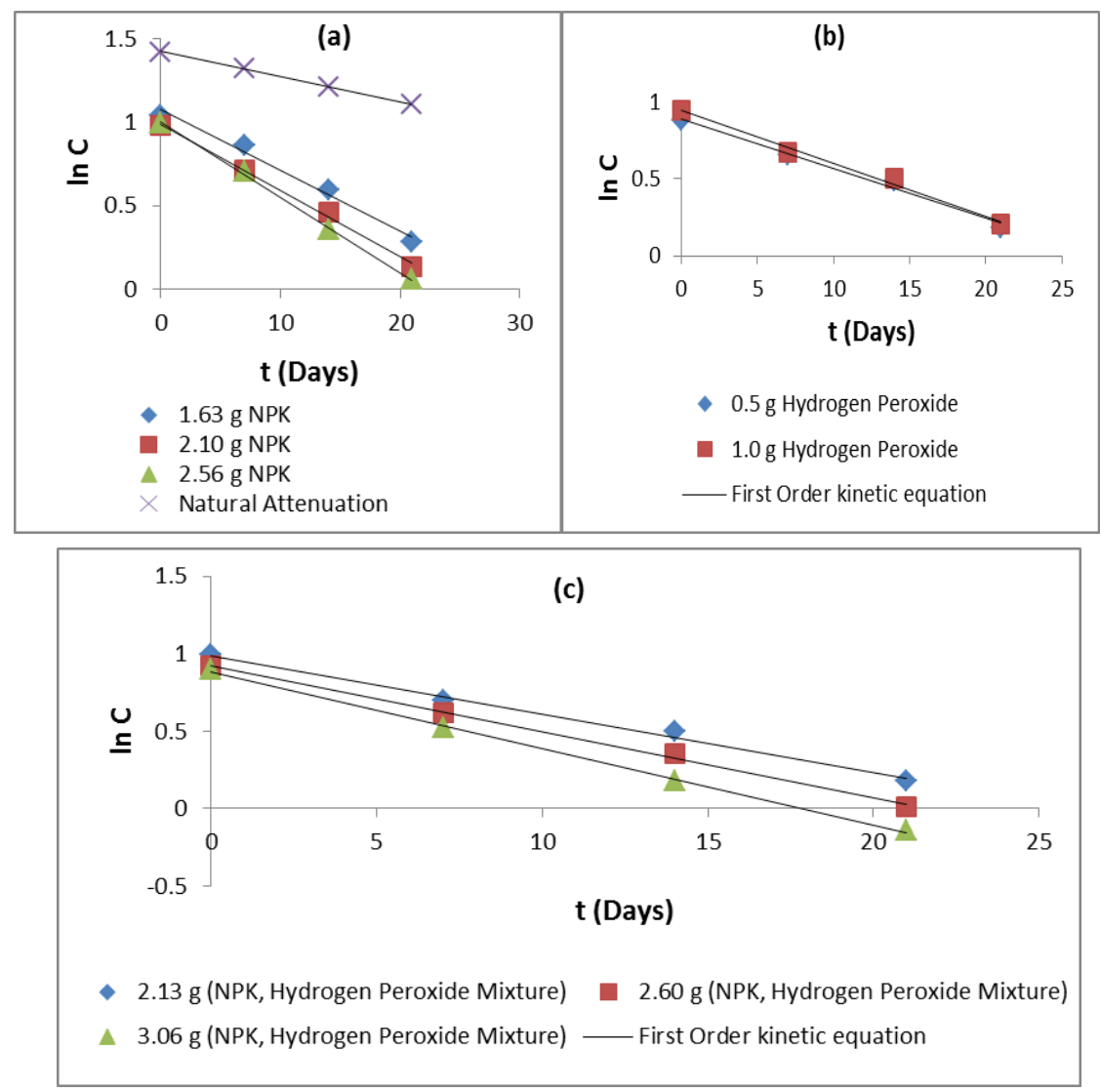

Figure 3: First-order kinetic model fitted to the biodegradation data of bitumen under the influence of (a) varying amount of NPK fertilizer, (b) varying amount of hydrogen peroxide, and (c) varying amount of combined NPK fertilizer+hydrogen peroxide. 
Citation: Agarry SE, Oghenejoboh KM (2014) Biodegradation of Bitumen in Soil and Its Enhancement by Inorganic Fertilizer and Oxygen Release Compound: Experimental Analysis and Kinetic Modelling. J Microbial Biochem Technol S4: 002. doi:10.4172/1948-5948.S4-002

\begin{tabular}{|c|c|c|c|c|}
\hline Factors & $\begin{array}{c}\text { First-Order } \\
\text { Kinetic Equation }\end{array}$ & $k\left(\right.$ day $\left.^{-1}\right)$ & $R^{2}$ & $\begin{array}{l}\text { Half-life } t_{1 / 2} \\
\quad \text { (days) }\end{array}$ \\
\hline \multicolumn{5}{|l|}{ NPK-amended soil } \\
\hline $1.63 \mathrm{~g}$ & $C=-0.036 t+1.075$ & 0.036 & 0.984 & 19.3 \\
\hline $2.10 \mathrm{~g}$ & $C=-0.039 t+0.991$ & 0.039 & 0.997 & 17.8 \\
\hline $2.56 \mathrm{~g}$ & $C=-0.045 t+1.003$ & 0.045 & 0.998 & 15.4 \\
\hline \multicolumn{5}{|l|}{$\begin{array}{l}\text { Hydrogen peroxide- } \\
\text { amended soil }\end{array}$} \\
\hline $0.5 \mathrm{~g}$ & $C=-0.032 t+0.887$ & 0.032 & 0.986 & 21.7 \\
\hline $1.0 \mathrm{~g}$ & $C=-0.034 t+0.940$ & 0.034 & 0.989 & 20.4 \\
\hline \multicolumn{5}{|l|}{$\begin{array}{l}\text { NPK+Hydrogen } \\
\text { peroxide-amended soil }\end{array}$} \\
\hline $2.13 \mathrm{~g}$ & $C=-0.037 t+0.987$ & 0.037 & 0.992 & 18.7 \\
\hline $2.60 \mathrm{~g}$ & $C=-0.042 t+0.926$ & 0.042 & 0.997 & 16.5 \\
\hline $3.06 \mathrm{~g}$ & $C=-0.049 t+0.882$ & 0.049 & 0.998 & 14.2 \\
\hline $\begin{array}{l}\text { Unamended soil } \\
\text { (Natural attenuation) }\end{array}$ & $C=-0.014 t+1.422$ & 0.014 & 0.999 & 49.5 \\
\hline
\end{tabular}

here can be a relevant support tool when designing bioremediation strategies on site.

\section{References}

1. Gbolahan-Ayoade EE, Gbolahan WA, Oluwaseun A (2014) Environmental impact of aerophilic organisms on bitumen biodegradation. Int $\mathrm{J}$ Sci Res Pub 4: $1-5$.

2. Adegoke OS (2000) Historical perspective of bitumen/tar sand development in Southwestern Nigeria. Proceedings of the 1st International Summit on Bitumen in Nigeria, Nov. 14-16, Akure, Nigeria, pp: 131-140.

3. Oboh OB, llori MO, Akinyemi JO, Adebusoye SA (2006) Hydrocarbon degrading potentials of bacteria [2] isolated from a Nigerian bitumen (Tarsand) deposit. Nat Sci 4: 51-58

4. Strausz OP, Morales-Izquierdo A, Kazmi N, Montgomery DS, Payzant JN, et al. (2010) Chemical composition of athabasca bitumen: The saturate fraction Energy Fuels 24: 5053-5072.

5. Yoon S, Bhatt SD, Lee W, Lee HY, Jeong SY, et al. (2009) Separation and characterization of bitumen from Athabasca oil sand. Korean J Chem Eng 26: 64-71.

Table 1: First-order kinetic equation with correlation determination $\left(\boldsymbol{R}^{2}\right)$ results of bitumen biodegradation under the influence of inorganic fertilizer and oxygen release compound.

is the biodegradation rate constants, the higher or faster is the rate of biodegradation and consequently the lower is the half-life time. It could be seen from Table 1 that for NPK-soil amended microcosms, the soil microcosm amended with $2.56 \mathrm{~g}$ NPK fertilizer had a higher $k(0.045$ day $\left.^{-1}\right)$ and lower $t_{1 / 2}$ (15.4 days) than that amended with $2.10 \mathrm{~g}$ NPK ( $k=0.039$ day $^{-1}$ and $t_{11}=17.8$ days $)$ and $1.63 \mathrm{~g} \mathrm{NPK}\left(k=0.036 \mathrm{day}^{-1}\right.$ and $t_{1}=19.3$ days), respectively. For oxygen release compound (hydrogen peroxide)-soil amended microcosms, the soil amended with $1.0 \mathrm{~g}$ of hydrogen peroxide had a relatively higher $k\left(0.034\right.$ day $\left.^{-1}\right)$ and lower $t_{1 / 2}$ (20.4 days) than the one amended with $0.5 \mathrm{~g}$ of hydrogen peroxide ( $k=0.032$ day $^{-1}$ and $t_{1 / 2}=21.7$ days). Furthermore, the soil amended with $3.06 \mathrm{~g}$ NPK and hydrogen peroxide mixture had a higher $k$ ( 0.049 day $\left.{ }^{1}\right)$ and lower $t_{1 / 2}$ (14.2 days) than that amended with $2.60 \mathrm{~g} \mathrm{NPK}$ and hydrogen peroxide mixture $\left(k=0.042\right.$ day $^{-1}$ and $t_{1 / 2}=16.5$ days $)$ and $2.13 \mathrm{~g}$ NPK and hydrogen peroxide mixture $\left(k=0.037 \mathrm{day}^{-1}\right.$ and $t_{1 / 2}=18.7$ days $)$, respectively. A biodegradation rate constant $(k)$ of 0.042 day $^{-1}$ and half-life time $\left(t_{1 / 2}\right)$ of 49.5 days was observed for the biodegradation of bitumen in soil not amended with biostimulant (natural attenuation).

\section{Conclusions}

The present studies confirm that the use of inorganic nutrient such as NPK fertilizer and oxygen release compound (hydrogen peroxide) improved the rate of biodegradation in microcosms simulating soil or land environments contaminated with bitumen oil. At the end of 21 days remediation period, the maximum Total Petroleum Hydrocarbon (TPH) removal that ranged from $53.2 \%$ to $60.8 \%, 50.1 \%$ to $52.2 \%$ and $55.6 \%$ to $64.5 \%$ was obtained for bitumen-contaminated soil amended with different amount of NPK fertilizer (1.63-2.56 g), hydrogen peroxide $(0.5$ and $1.0 \mathrm{~g})$, and combined amount of NPK fertilizer and hydrogen peroxide $(2.13 \mathrm{~g}, 2.60 \mathrm{~g}$ and $3.06 \mathrm{~g})$, respectively. The biodegradation rate constant obtained from the application of first order kinetics described the rate of bitumen oil biodegradation with and without biostimulant. The rate constant $(k)$ ranges between 0.032 day $^{-1}$ and 0.049 day $^{-1}$ for amended soil microcosm and 0.014 day $^{-1}$ for unamended soil microcosm (natural attenuation). A half-life time $\left(t_{1 / 2}\right)$ of 49.5 days was observed for biodegradation of bitumen oil in soil not amended with biostimulant. This was reduced to between 14.2 and 21.7 days with the usage of different amount of biostimulant in the form of inorganic NPK fertilizer, hydrogen peroxide (oxygen release compound) and their combinations. These findings do not represent a general rule and site-specific studies are needed, the approach used

6. Spirov P, Rudyk S, Tyrovolas A, Jimoh I (2013) The bitumen extraction from Nigerian tar sand using dense carbon dioxide. Chem Eng Transact 32: 283288

7. Oguntimehin II, Ipinmoroti KO (2007) Solvent extraction of vanadium from Nigerian bitumen using tri-buthylphosphate. J Appl Sci 7: 4028-4031.

8. Bejarano AC, Michel J (2010) Large-scale risk assessment of polycyclic aromatic hydrocarbons in shoreline sediments from Saudi Arabia: environmental legacy after twelve years of the Gulf war oil spill. Environ Pollut 158: 1561-1569.

9. Okoh Al (2006) Biodegradation alternative in the cleanup of petroleum hydrocarbon pollutants. Biotechnol Mol Biol Rev 1: 38 -50.

10. Desai JD, Banat IM (1997) Microbial production of surfactants and their commercial potential. Microbiol Mol Biol Rev 61: 47-64.

11. Rahman KS, Banat IM, Thahira J, Thayumanavan T, Lakshmanaperumalsamy $P(2002)$ Bioremediation of gasoline contaminated soil by a bacterial consortium amended with poultry litter, coir pith and rhamnolipid biosurfactant. Bioresour Technol 81: 25-32.

12. Nduka JK, Umeh LN, Okerulu IO, Umedum LN, Okoye HN (2012) Utilization of Different Microbes in Bioremediation of Hydrocarbon Contaminated Soils Stimulated With Inorganic and Organic Fertilizers. J Pet Environ Biotechnol $3: 116$.

13. Bonaventura C, Johnson FM (1997) Healthy environments for healthy people: bioremediation today and tomorrow. Environ Health Perspect 105 Suppl 1 5-20.

14. Walter M, Boyd-Wilson, KSH, McNaughton D, Northcott G (2005) Laboratory trials on the bioremediation of aged pentachlorophenol residues. Int Biodeterior Biodegradation 55: 121-130.

15. Kao CM, Chen CY, Chen SC, Chien HY, Chen YL (2008) Application of in situ biosparging to remediate a petroleum-hydrocarbon spill site: field and microbial evaluation. Chemosphere 70: 1492-1499.

16. Ayotamuno MJ, Kogbara RB, Ogaj SOT, Probert SD (2006) Bioremediation of a crude-oil polluted agricultural-soil at Port Harcourt, Nigeria. Appl Energy 83: 1249-1257.

17. Agarry SE, Owabor CN, Yusuf RO (2010a) Bioremediation of soil artificially contaminated with petroleum hydrocarbon mixtures: Evaluation of the use of animal manure and chemical fertilizer. Bioremediat J 14: 189-195.

18. Tsai TT, Kao CM, Surampalli RY, Chien HY (2009) Enhanced Bioremediation of Fuel-Oil Contaminated Soils: Laboratory Feasibility Study. J Environ Eng 135: $845-853$

19. Maiti A, Das S, Bhattacharyya N (2012) Bioremediation of high molecular weight polycyclic aromatic hydrocarbons by Bacillus thuringiensis strain NA2. J Science 1: 72-75

20. Agarry SE, Owabor CN, Yusuf RO (2012) Enhanced bioremediation of soi artificially contaminated with kerosene: Optimization of biostimulation agents through statistical experimental design. J Pet Environ Biotechnol 3:120. 
Citation: Agarry SE, Oghenejoboh KM (2014) Biodegradation of Bitumen in Soil and Its Enhancement by Inorganic Fertilizer and Oxygen Release Compound: Experimental Analysis and Kinetic Modelling. J Microbial Biochem Technol S4: 002. doi:10.4172/1948-5948.S4-002

21. Borah D, Yadav RN (2014) Biodegradation of complex hydrocarbon by a novel Bacillus cereus strain. J Environ Sci Technol 2014: 1-9

22. Zhang S, Wang X, Zhu R, Li H, Wang P, et al. (2014) Aerobic biodegradation of trichloroethylene by a bacterial community that uses hydrogen peroxide as sole oxygen source.

23. Ferguson SH, Woinarski AZ, Snape I, Morris CE, Revill AT (2004) A field trial of in situ chemical oxidation to remediate long-term diesel contaminated Antarctic soil. Cold Regions Sci Technol 40: 47-60.

24. Lodha B, Chaudhari S (2007) Optimization of Fenton-biological treatment scheme for the treatment of aqueous dye solutions. J Hazard Mater 148: 459466.

25. Olabemiwo OM, Adediran GO, Adekola FA, Adelowo OO, Olajire AA (2011) Preliminary study on biodegradation of Nigerian natural bitumen. Microbiology J 1: 139-148.

26. Oloke JK, Adebayo EA, Aina DA (2009) Effect of nitrogen and phosphate limitation on utilization of bitumen and production of bitu-oil and gas by a bacterial consortium. Afri J Biotechnol 8: 6871-6879.

27. Black CA (1965) Method of Soil Analysis II. American Society of Agronomy Madison, WI 573-590.

28. Ferreira FL, de Lucas J, do Amaral LA (2003) Partial characterization of the polluting load of swine wastewater treated with an integrated biodigestion system. Bioresour Technol 90: 101-108.

29. Watwood ME, White CS, Dahm CN (1991) Methodological modifications for accurate and efficient determination of contaminant biodegradation in unsaturated calcareous soils. Appl Environ Microbiol 57: 717-720.

30. Greene EA, Kay JG, Jaber K, Stehmeier LG, Voordouw G (2000) Composition of soil microbial communities enriched on a mixture of aromatic hydrocarbons. Appl Environ Microbiol 66: 5282-5289

31. Quintero JC, Moreira MT, Feijoo G, Lema JM (2005) Anaerobic degradation of hexachlorocyclohexane isomers in liquid and soil slurry systems. Chemosphere 61: 528-536.

32. Olabemiwo OM, Adediran GO, Adekola FA, Adelowo OO, Olajire AA (2014) Biodegradation of hydrocarbon compounds in Agbabu natural bitumen. Afri $J$ Biotechnol 13: 1257-1264.

33. Zhu X, Venosa AD, Suidan MT, Lee K (2001) Guidelines for the Bioremediation of Marine Shorelines and Freshwaters Waterlands. US Environmental Protection Agency Office of Research and Development National Risk Management Research Laboratory.

34. Jianlong W, Liping $H$, Hanchang S, Yi Q (2001) Biodegradation of quinoline by gel immobilized Burkholderia sp. Chemosphere 44: 1041-1046.

35. Aronson D, Boethling R, Howard P, Stiteler W (2006) Estimating biodegradation half-lives for use in chemical screening. Chemosphere 63: 1953-1960.

36. Sinkkonen S, Paasivirta J (2000) Degradation half-life times of PCDDs, PCDFs and PCBs for environmental fate modeling. Chemosphere 40: 943-949.

37. Dimitrov S, Pavlov T, Nedelcheva D, Reuschenbach P, Silvani M, et al. (2007) A kinetic model for predicting biodegradation. SAR QSAR Environ Res 18: 443457.

38. Matthies M, Witt J, Klasmeier J (2008) Determination of soil biodegradation half-lives from simulation testing under aerobic laboratory conditions: a kinetic model approach. Environ Pollut 156: 99-105

39. Zahed MA, Aziz HA, Isa MH, Mohajeri L, Mohajeri S, et al. (2011) Kinetic modeling and half life study on bioremediation of crude oil dispersed by Corexit 9500. J Hazard Mater 185: 1027-1031.
40. Agarry SE, Aremu MO, Aworanti OA (2013) Kinetic modelling and half-life study on bioremediation of soil co-contaminated with lubricating motor oil and lead using different bioremediation strategies. Soil and Sediment Contam An Int J 22: $800-816$

41. Yeung PY, Johnson RL, Xu JG (1997) Biodegradation of petroleum hydrocarbons in soil as affected by heating and forced aeration. $J$ Environ Quality 26: 1511-1576.

42. Tanee FBG, Kinako PDS (2008) Comparative studies of biostimulation and phytoremediation in the mitigation of crude oil toxicity in tropical soil. J Appl Sci Environ Manage 12: 143-147.

43. Mukherjee AK, Bordoloi NK (2012) Biodegradation of benzene, toluene, and xylene (BTX) in liquid culture and in soil by Bacillus subtilis and Pseudomonas aeruginosa strains and a formulated bacterial consortium. Environ Sci Pollut Res Int 19: 3380-3388.

44. Abu GO, Atu ND (2008) An investigation of oxygen limitation in microcosm models in the bioremediation of a typical Niger-Delta soil ecosystem impacted with crude oil. J Appl Sci Environ Manage 12: 13-22.

45. U S EPA (1991) Site Characterisation for sub-surface remediation. Seminar publication. EPA/625/4-91/026. Standard Guide for Ecological consideration for the use of Bioremediation in oil spill Response. Sand and Gravel Beaches. Fixed Designation: F 1481 and Standard Guide for Ecological consideration for the use of Bioremediation in oil spill Response. Land fixed designation: F 1693. Office of Research and Development, Washington D.C.

46. Joo HS, Ndegwa PM, Shoda M, Phae CG (2008) Bioremediation of oilcontaminated soil using Candida catenulata and food waste. Environ Pollut 156: 891-896.

47. Lee SH, Lee S, Kim DY, Kim JG (2007) Degradation characteristics of waste lubricants under different nutrient conditions. J Hazard Mater 143: 65-72.

48. Chorom M, Sharif HS, Mutamedi H (2010) Bioremediation of a crude oil-polluted soil by application of fertilizers. Iran J Environ Health Sci Eng 7: 319-326.

49. Zhou E, Crawford RL (1995) Effects of oxygen, nitrogen, and temperature on gasoline biodegradation in soil. Biodegradation 6: 127-140.

50. Agarry SE, Owabor CN, Yusuf RO (2010b) Studies on biodegradation of kerosene in soil under different bioremediation strategies. Bioremediation $\mathrm{J} 14$ $135-141$.
This article was originally published in a special issue, Chemical Engineering Science handled by Editor. Dr. Tingyue Gu, Ohio University, USA 